\begin{tabular}{cc|c}
\hline Tar. Bil. Der. & Journal of Agricultural Sciences \\
& $\begin{array}{c}\text { Dergi web sayfası: } \\
\text { www.agri.ankara.edu.tr/dergi }\end{array}$ & Journal homepage: \\
& www.agri.ankara.edu.tr/journal
\end{tabular}

\title{
Determination of the Body Condition Score and Its Relationship with Milk Yield in Turkish Holstein Cows
}

\author{
Aş̧kın GALİÇ \\ ${ }^{a}$ Akdeniz University, Faculty of Agriculture, Department of Animal Science, Antalya, TURKEY
}

\section{ARTICLE INFO}

Research Article $\quad$ DOI: 10.15832/ankutbd.385869

Corresponding Author: Akkēer GALKC, E-mail: galic@ akdeniz.edu.tr, Tel: +90 (242) 3102497

Received: 23 June 2016, Received in Revised Form: 01 September 2016, Accepted: 01 September 2016

\begin{abstract}
It is quite important to keep the condition of cows under surveillance due to conduct of nutritional programs in dairy herds as well as genetic relations with other traits. This study was conducted to estimate the heritability of body condition score (BCS) and genetic correlation with milk yield of Holstein cows. Also, the effects of herd, lactation period and calving age on BCS were investigated. For this aim, body conditions of 1001 cows were scored using the scale of 1-9. The average BCS was determined as $5.52 \pm 0.04$ and its average was ranged from 4.54 to 6.58 at different periods of lactation. Results showed that body conditions were affected by the lactation period significantly $(\mathrm{P}<0.01)$, while the effects of herd and calving age on it were not statistically significant. Heritability estimate of BCS was $0.20 \pm 0.16$ while the genetic correlation of BCS with milk yield was moderately negative $(-0.41 \pm 0.17)$ indicating that high-producing cows tend to be leaner. Although with high standard errors, these results indicates that BCS is heritable at low-moderate level and can result in a progress in both traits by defining an appropriate index.
\end{abstract}

Keywords: Body condition score; Energy balance; Genetic parameter; Milk yield

\section{Türk Siyah Alaca İneklerde Vücut Kondisyon Skoru ve Süt Verimi ile Arasındaki İlişkinin Belirlenmesi}

\section{ESER BİLGİsi}

Araştırma Makalesi

Sorumlu Yazar: Aşkın GALİÇ, E-posta: galic@akdeniz.edu.tr, Tel: +90 (242) 3102497

Geliş Tarihi: 23 Haziran 2016, Düzeltmelerin Gelişi: 01 Eylül 2016, Kabul: 01 Eylül 2016

\section{ÖZET}

Gerek işletmedeki besleme programının yürütülmesi, gerekse diğer özelliklerle olan genetik ilişkisi nedeniyle, ineklerin kondisyonlarının gözlem altında tutulması oldukça önemlidir. Bu çalışma, Siyah Alaca ineklerde vücut kondisyon skorunun (VKS) kalıtım derecesi ve süt verimi ile arasındaki ilişkinin belirlenmesi amacıyla yürütülmüştür. Ayrıca, işletme, laktasyon dönemi ve buzağılama yaşının VKS'ye etkisi araştırılmıştır. Bu amaçla 1001 ineğin vücut kondisyonları 1-9'luk ölçeğe göre puanlanmıştır. VKS'ye ait ortalama 5.52 \pm 0.04 olarak bulunmuş olup farklı laktasyon dönemlerinde VKS ortalamaları 4.54 ile 6.58 arasında değişmiştir. İçinde bulunulan laktasyon döneminin, 
hayvanların vücut kondisyonu üzerine önemli etkiler yaptığı $(\mathrm{P}<0.01)$, işletme ve ilk buzağılama yaşının etkilerinin ise istatistiksel olarak önemli olmadığı belirlenmiştir. VKS'ye ait kalıtım derecesi $0.20 \pm 0.16$ iken, süt verimi ile arasındaki genetik korelasyon $-0.41 \pm 0.17$ olarak tahmin edilmiştir ki bu da yüksek süt verimine sahip ineklerin daha zayıf yapılı olma eğiliminde oldukları anlamına gelmektedir. Standart hataları yüksek olmakla beraber elde edilen bu sonuçlar, VKS'nin düşük-orta düzeyde kalıtsal olduğunu ve uygun indeks belirlenerek ele alınan her iki özellikte de ilerleme sağlanabileceğini göstermektedir.

Anahtar Kelimeler: Vücut kondisyon skoru; Enerji dengesi; Genetik parametre; Süt verimi

(C) Ankara Üniversitesi Ziraat Fakültesi

\section{Introduction}

Bovine meat and milk are essential to meet the need for animal protein that is indispensable for human beings. Holstein is globally the most widely reared cattle breed. For long years, a variety of studies on animal breeding have traditionally focused on the milk yield as well as the fat and protein content of the milk (Gallo et al 2001). Pushing animal health and reproduction into the background resulted in animals with high yield values but poor health and fertility (Grosshans et al 1997; Evans et al 2002; Royal et al 2002a; Berry et al 2003).

Energy balance in dairy cattle can be defined as the difference between the energy taken into the body and the energy being used for the functions of daily living and for yield (Koenen et al 2001). Energy balance is negative during the early stages of lactation, which is regarded as normal for mammals (Robinson 1986; Berglund \& Danell 1987).

Targeting high yield in animal breeding can lead to energy imbalances. It should be remembered that the duration and severity of such energy imbalances will cause problems on reproduction and health (Butler \& Smith 1989; Veerkamp et al 2001). This is because the high yielding animals tend to make up this energy deficit to a large extent by activating their tissue reserves (Veerkamp \& Emmans 1995; Dechow et al 2002; Loker et al 2012). What is ideal is to select the animals exercising satisfactory levels of yield, but in the meanwhile, not over using their tissue reserves. That may also mean the selection of animals which consume more feed to compensate the energy imbalance.
Body condition scoring is a method that is routinely used to assess the body fat and energy levels of the cows (Wildmann et al 1982; Kadarmideen 2004). It has gained popularity since it fosters indirect improvement of the reproduction performance and health indairy cows (Pryce et al 2000; Kadarmideen \& Wegmann 2003). A variety of methods and scales are used for evaluating the body condition, the ultimate goal of which is to find out the amount of metabolic energy lying inert under the fat and muscle tissues of the animals. Assessing the body condition with ultrasound gives more accurate results, yet it is more expensive and less convenient to be used widely on the ground (Domecq et al 1995). Although it is a subjective method, visual evaluation is easily applicable, accurate enough to show the variations of body reserves among animals of the same breed, and it can be used to determine the ratio of the fat metabolization with reasonable accuracy (Waltner et al 1994; Enevoldsen \& Kristensen 1997). Therefore, the subjective method for assessing the body condition score (BCS) was approved and recommended by the International Committee for Animal Recording (ICAR 2004).

There are very recent studies on the potential benefits of body condition scoring for breeding programs, which plays an important role to assess and regulate the caring and nutrition. The objective is to increase the frequency of genotypes in the population that have optimal condition and whose condition scores do not change significantly in the successive periods rather than the over-fat or underweight genotypes. According to Veerkamp \& Brotherstone (1997), selection for increased milk yield while maintaining BCS at its current level 
results in a reduction of overall (economic) genetic gain by $5 \%$. However, this study disregarded the reduction in cost that resulted from the improved health and reproduction.

Although the change in the body condition during lactation is slightly heritable, the heritability of the body condition level is around $0.20-0.50$ (Koenen et al 2001; Loker et al 2012; Bastin \& Gengler 2013). Several researchers estimated the correlation between BCS and yield, which generally turned out to be negative (Veerkamp et al 2001; Berry et al 2003; Dal Zotto et al 2007; Loker et al 2012). While it was found that the effect of BCS on embryo quality characteristics and milk composition was not important (Ayaşan et al 2012a; 2012b), Bastin \& Gengler (2013) reported that the cows with higher BCS are also better in terms of reproduction.

$\mathrm{BCS}$ is expected to become more important in animal breeding programs because the heritability is medium, and it shows low to medium genetic correlation with economically important traits. The findings of the studies on this topic have revealed that selection might be based on the body condition without a significant negative impact on the milk yield. Therefore, any information about the genetic variation in terms of body condition and its correlation with the milk yield can be helpful to plan breeding programs for dairy cattles. This study aims to discover the heritability of BCS and itsrelationship with milk yield as well as some environmental factors affecting the BCS.

\section{Material and Methods}

This study used the data regarding the Holstein cows from 3 herds, all of which are the members of Cattle Breeders' Association of Antalya, Turkey. The records of the animals-i.e, date of birth and calving-were taken from the database of the Cattle Breeders' Association of Antalya. 1001 animals in the herds were scored by the same person using 1-9 scale as recommended by ICAR (Figure 1). All the cows within a herd were scored on the same day. When estimating the heritability, scores of 965 animals whose age at first calving ranges from 20 to 40 months were evaluated (Table 1). Moreover, 668 of these animals with lactation milk yield $\geq 1,000 \mathrm{~kg}$ were used to discover the correlation between BCS and lactation milk yield.

SPSS was used to estimate the descriptive values and the effects of fixed environmental factors. The model used for this is shown in Equation 1.

$$
\mathrm{Y}_{\mathrm{ijkl}}=\mu+h_{\mathrm{i}}+l p_{\mathrm{j}}+c a_{\mathrm{k}}+\mathrm{e}_{\mathrm{ijkl}}
$$

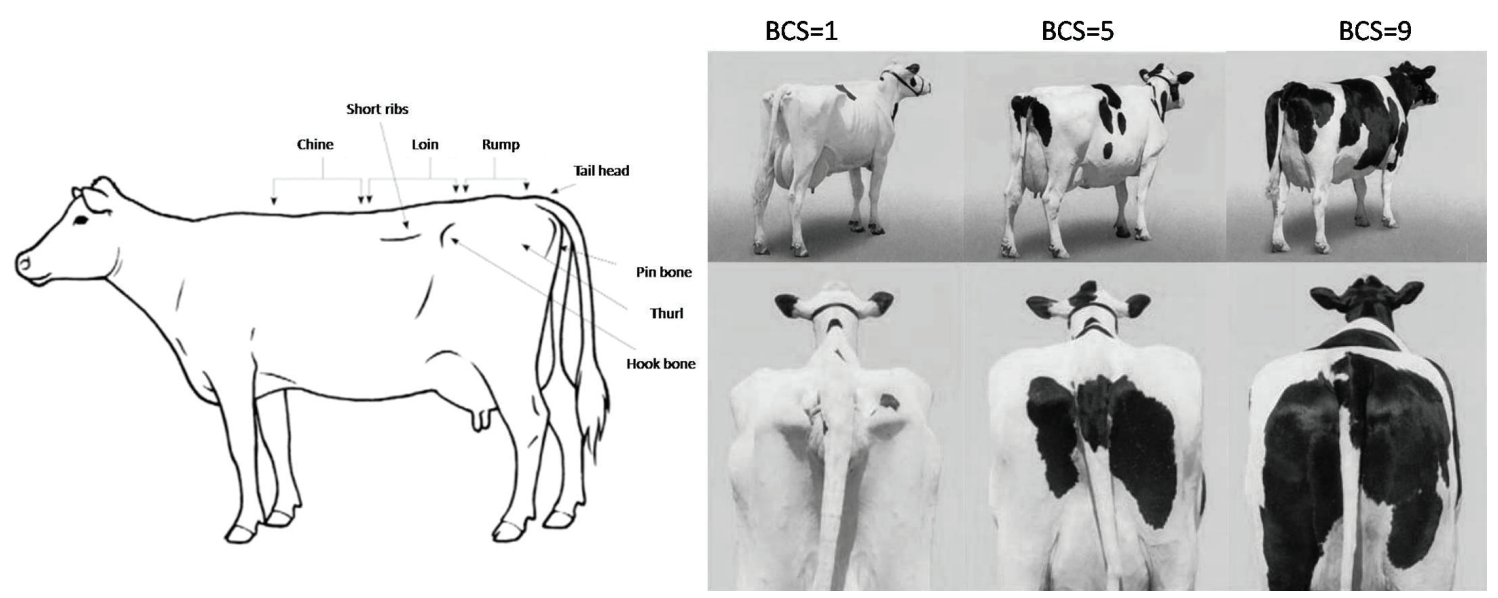

Figure 1- Anatomic regions used to evaluate body condition and examples of cows with different conditions (NFACC 2016; Kellogg 2016) 
Where; $Y_{i j k l}$, body condition score; $\mu$, mean; $h_{\mathrm{i}}$, herd effect; $l p_{\mathrm{j}}$, lactation period (month) effect; $c a_{\mathrm{k}}$, calving age effect; $\mathrm{e}_{\mathrm{ijkl}}$, the random residual.

Table 1- Details about the file used to estimate the heritability of BCS

\begin{tabular}{lr}
\hline Parameter & Value \\
\hline Number of records & 965 \\
Number of dams & 951 \\
Number of sires & 669 \\
Total number of animals & 2478 \\
Average number of daughter per sire & 1.44 \\
Number of inbred animals & 1 \\
Average of inbreeding coefficient & 0.25 \\
\hline
\end{tabular}

MTDFREML was used to estimate the heritability of BCS and the relationship with milk yield. Univariate animal model were used to estimate the heritability while multivariate animal models were used to estimate the correlation. Such models are given in Equation 2 and 3 (Mrode 1996).

$y=X b+Z a+e$

$\left[\begin{array}{l}y_{1} \\ y_{2}\end{array}\right]=\left[\begin{array}{cc}X_{1} & 0 \\ 0 & X_{2}\end{array}\right]\left[\begin{array}{l}b_{1} \\ b_{2}\end{array}\right]+\left[\begin{array}{cc}Z_{1} & 0 \\ 0 & Z_{2}\end{array}\right]\left[\begin{array}{l}a_{1} \\ a_{2}\end{array}\right]+\left[\begin{array}{l}e_{1} \\ e_{2}\end{array}\right] \ldots$

(1= BCS, $2=$ milk yield $)$

Where; $X$, fixed design matrix; $Z$, random design matrix; $b$, fixed factors that are the herd and the month of lactation when the scoring was exercised, in which the age at first calving is excluded since it does not contribute to the reliability of the model; $a$ and $e$, additive genetic effect vector and the error vector-which are random factors, respectively.

\section{Results and Discussion}

Figure 2 displays the distribution of animals included in this study by their BCS. The most common score was 5 . No animal was scored with 1 and only $2 \%$ of the animals were scored with 2 and 9 . Neither on 1-5 scale nor on 1-9 scale, the cows were supposed to be scored lower than 2 . Besides, almost $77 \%$ of 1001 cows were scored in 4-6 range, which means that the body condition of the cows are neither underweighted nor fat. This can be interpreted as a very positive finding of the study.

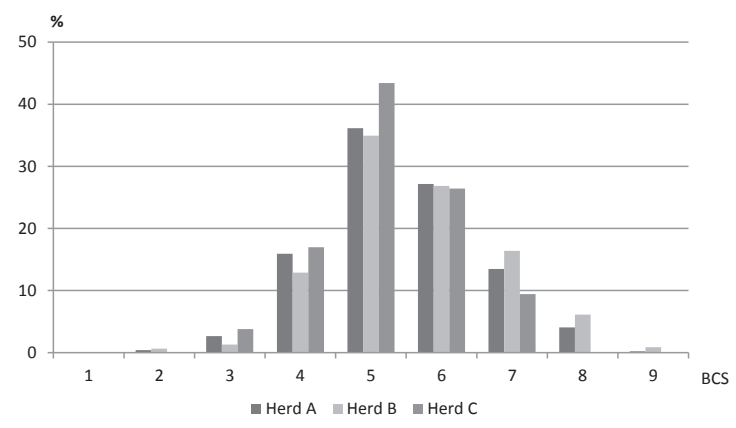

Figure 2- Distribution of animals' BCS according to the herds

The analysis showed that the average scores of the herds were very close to each other. Similarly, there was a slight difference in the body conditions of the animals that have different ages at first calving; however, this difference was not statistically significant. On the other hand, a statistical significance was discovered regarding the effect of the period of lactation at the time of scoring on the BCS $(\mathrm{P}<0.01)$. Average BCS by months ranged from 4.54 to 6.58 (Table 2). The means of lactation milk yields were also given at the Table. It was sure to have the lowest score in the early stages of lactation, considering the negative energy balance that the cows are in inevitably because they failed to meet the energy need caused by high milk yield after calving. Cows have loss of condition because they regulate the energy imbalance with their body fats. This situation disappears progressively resulting in an increase in BCS. In this study, the score also improved in the later stages of lactation despite small fluctuations. The extreme variations in the latest stages are considered to be associated with the low number of animal in the groups and the extreme values that these animals display. On the other hand, the difference between the highest and the lowest BCS in the lactation period was supposed to be no bigger than 4 on 1-9 scale (Staples et al 1992; Ruegg \& Milton 1995; ADLIB 2001a). Table 2 shows that this difference is around 2 only in the study material. 
Table 2- Body condition scores and average lactation milk yields of animals in different periods of lactation

\begin{tabular}{ccccccc}
\hline \multirow{2}{*}{$\begin{array}{c}\text { Lactation period } \\
\text { (month) }\end{array}$} & \multicolumn{3}{c}{ Body condition score } & \multicolumn{2}{c}{ Lactation milk yield } \\
\cline { 2 - 7 } & $N$ & Mean \pm SE $^{*}$ & Minimum & Maximum & $N$ & Mean \\
\hline 1 & 45 & $5.04 \pm 0.159^{\mathrm{ab}}$ & 3 & 7 & 31 & $9,444.58$ \\
2 & 70 & $4.54 \pm 0.116^{\mathrm{a}}$ & 2 & 7 & 43 & $8,633.42$ \\
3 & 107 & $4.94 \pm 0.084^{\mathrm{ab}}$ & 2 & 7 & 73 & $8,419.89$ \\
4 & 95 & $5.08 \pm 0.101^{\mathrm{ab}}$ & 2 & 8 & 74 & $8,515.30$ \\
5 & 82 & $5.13 \pm 0.099^{\mathrm{b}}$ & 3 & 8 & 50 & $8,450.56$ \\
6 & 73 & $5.16 \pm 0.107^{\mathrm{b}}$ & 3 & 7 & 46 & $9,440.43$ \\
7 & 39 & $5.31 \pm 0.152^{\mathrm{b}}$ & 3 & 7 & 26 & $8,743.19$ \\
8 & 41 & $5.27 \pm 0.140^{\mathrm{b}}$ & 3 & 7 & 31 & $9,238.35$ \\
9 & 53 & $5.40 \pm 0.143^{\mathrm{b}}$ & 3 & 8 & 42 & $9,598.17$ \\
10 & 49 & $6.12 \pm 0.122^{\mathrm{cd}}$ & 4 & 8 & 34 & $9,121.50$ \\
11 & 60 & $5.98 \pm 0.125^{\mathrm{c}}$ & 4 & 8 & 39 & $9,919.05$ \\
12 & 70 & $6.11 \pm 0.126^{\mathrm{cd}}$ & 4 & 9 & 50 & $9,676.68$ \\
13 & 51 & $6.39 \pm 0.146^{\mathrm{cd}}$ & 4 & 8 & 34 & $9,922.56$ \\
14 & 43 & $6.58 \pm 0.174^{\mathrm{d}}$ & 4 & 9 & 30 & $10,567.60$ \\
15 & 24 & $5.96 \pm 0.299^{\mathrm{c}}$ & 3 & 9 & 13 & $9,914.31$ \\
16 & 16 & $6.44 \pm 0.288^{\mathrm{cd}}$ & 4 & 8 & 11 & $10,506.64$ \\
17 & 83 & $6.29 \pm 0.134^{\mathrm{cd}}$ & 4 & 9 & 41 & $8,957.78$ \\
\hline
\end{tabular}

a,b,c, means with different superscripts letter differ significantly at $\mathrm{P}<0.01{ }^{*}$, standard error

The changes reported in different stages of lactation were parallel to the findings of various other studies (Gallo et al 1996; Dechow et al 2001; Çoban 2006; Şahin 2011; Karslıoğlu Kara 2015). Having a BCS of 5.04 at the beginning of the lactation was slightly below the optimal values that were reported by various other researchers (Staples et al 1992; ADLIB 2001b; Karslığlu Kara 2015). However, in the subsequent months when the animals had peak lactation, the body condition scores were at the required level, which implies the absence of a general problem.

Table 3 shows the parameters derived from the analysis. Heritability of BCS was $0.20 \pm 0.16$. This was smaller than the values reported as 0.33 , 0.38 , and 0.28 by Gallo et al (2001), Veerkamp et al (2001) and Royal et al (2002b), respectively but bigger than the values reported as 0.07-0.09 for dry period by Dechow et al (2001). The heritability was similar to the estimates of Koenen et al (2001) as 0.24 , Dechow et al (2004) as 0.20 and Vallimont et al (2010) as 0.26 . On the other hand, the genetic correlation in the analysis was $-0.41 \pm 0.17$ between $\mathrm{BCS}$ and milk yield. This value was higher than the values reported as -0.12 by Kadarmideen \& Wegmann (2003) and as -0.28 by Loker et al (2012). However, it was very similar to the values reported as -0.39 and -0.40 by Battagin et al (2013) and Dal Zotto et al (2007), respectively. Bastin \& Gengler (2013) discovered a negative correlation that ranges from -0.63 to -0.12 in their review article. In other words, the cows with genetically high yield tend to have low BCS particularly in the lactation period. The differences reported by the above-mentioned studies can be related to the data source (field dataresearch data), the scale used to evaluate the body condition, the statistical model used, the number and period of lactation, breeds, the number of records per animal, and the procedures of data editing (Dal Zotto et al 2007; Bastin \& Gengler 2013).

Table 3- Some parameters related to BCS

\begin{tabular}{lr}
\hline Parameter & Value \\
\hline Additive genetic variance & 0.20 \\
Error variance & 0.72 \\
Phenotypic variance & 0.92 \\
Heritability & 0.22 \\
Additive genetic correlation with milk yield & -0.41 \\
Phenotypic correlation with milk yield & -0.10 \\
\hline
\end{tabular}




\section{Conclusions}

Compared to other traits, BCS has an advantage in terms of acceptability by the breeders. Because they usually do not favor breeding programs that either intend to improve reproduction through selection on the basis of low milk yield or take into account the characteristics such as body depth, rump angle, and front udder attachment. Therefore, BCS is a trait that can be used indirectly to improve lactation milk yield and reproduction. Studies on the subject discovered that there is generally a high correlation among the BCS evaluated within and between parity. Therefore, a selection that is based on the BCS at the first lactation is also effective on the subsequent lactations (Bastin \& Gengler 2013).

The results showed that, $22 \%$ of phenotypic variation of $\mathrm{BCS}$ is due to genetic factors. This means that it is not impossible to achieve a change in the desired direction at BCS with selection of proper parents. Moreover, since the correlation between the two traits is not 1:1 (absolute), this can result in a progress in both traits by defining an appropriate index. What is prominent here is that the standard error associated with the genetic correlation is high. This is possibly related to the small dataset and the absence of some data about pedigree particularly about sires. BCS data should be collected and analysed more extensively and for longer time period to have more reliable estimates. Evaluating the body condition of each animal at different stages of lactation will not only increase reliability but also give a clue about the changes in body condition during lactation.

\section{Acknowledgements}

This study was financially supported by the Scientific Research Projects Unit of Akdeniz University under the project number of 2014.01.0104.006.

\section{References}

ADLIB (2001a). Fertility and Body Condition Score: Too Fat or Too Thin? http://www.adlib.ac.uk/ resources/000/243/943/Fertility_Body_Condition_ Score_2.pdf (Accessed date: 06.03.2015)
ADLIB (2001b). Fertility and Body Condition Score: Interpreting Condition Score Data. http://www. adlib.ac.uk/resources/000/243/942/Fertility_Body_ Condition_Score_1.pdf (Accessed date: 06.03.2015)

Ayaşan T, Asarkaya A, Hızlı H, Gök K, Tekgül A, Karakozak E, Kara U, Seğmenoğlu M S, Çoban, S, Mutlu H \& Kılıçalp N (2012a). Siyah alaca ineklerde vücut kondüsyon skorunun embriyo kalitesine etkisi. Kafkas Üniversitesi Veteriner Fakültesi Dergisi 18(1): 91-94

Ayaşan T, Yazgan E \& Asarkaya A (2012b). Vücut kondisyon skorunun süt komposizyonuna olan etkisi. Erciyes Üniversitesi Veteriner Fakültesi Dergisi 9(2): 89-93

Bastin C \& Gengler N (2013). Genetics of body condition score as an indicator of dairy cattle fertility: A review. Biotechnology, Agronomy, Society and Environment 17(1): 64-75

Battagin M, Sartori C, Biffani S, Penasa M \& Cassandro M (2013). Genetic parameters for body condition score, locomotion, angularity, and production traits in Italian Holstein cattle. Journal of Dairy Science 96(8): 5344-5351

Berglund B \& Danell B (1987). Live weight changes, feed consumption, milk yield and energy balance in dairy cattle during the first period of lactation. Acta Agriculturae Scandinavica 37(4): 495-509

Berry D P, Buckley F, Dillon P, Evans R D, Rath M \& Veerkamp R F (2003). Genetic relationships among body condition score, body weight, milk yield, and fertility in dairy cows. Journal of Dairy Science 86(6): 2193-2204

Butler W R \& Smith R D (1989). Interrelationships between energy balance and postpartum reproductive function in dairy cattle. Journal of Dairy Science 72(3): 767-783

Çoban Y (2006). Antalya'da Siyah Alaca 1rk1 ineklerin beden kondisyonları üzerine bir araştırma. Yüksek lisans tezi, Akdeniz Üniversitesi Fen Bilimleri Enstitüsü (Basılmamış), Antalya

Dal Zotto R, De Marchi M, Dalvit C, Cassandro M, Gallo L, Carnier P \& Bittante G (2007). Heritabilities and genetic correlations of body condition score and calving interval with yield, somatic cell score, and linear type traits in Brown Swiss cattle. Journal of Dairy Science 90(12): 5737-5743

Dechow C D, Rogers G W \& Clay J S (2001). Heritability and correlations among body condition scores, 
production traits and reproductive performance. Journal of Dairy Science 84(1): 266-275

Dechow C D, Rogers G W \& Clay J S (2002). Heritability and correlations among body condition score loss, body condition score, production and reproductive performance. Journal of Dairy Science 85(11): 30623070

Dechow C D, Rogers G W, Klei L \& Lawlor T J (2004). Heritability and correlations for body condition score and dairy form within and across lactation and age. Journal of Dairy Science 87(3): 717-728

Domecq J J, Skidmore A L, Lloyd J W \& Kaneene J B (1995). Validation of body condition score with ultrasound measurements of subcutaneus fat of dairy cows. Journal of Dairy Science 78(10): 2308-2313

Enevoldsen C \& Kristensen T (1997). Estimation of body weight from body size measurements and body condition scores in dairy cows. Journal of Dairy Science 80(9): 1988-1995

Evans R D, Buckley F, Dillon P \& Veerkamp R F (2002). Genetic parameters for production and fertility in spring-calving Irish dairy cattle. Irish Journal of Agricultural and Food Research 41(1): 43-54

Gallo L, Carnier P, Cassandro M, Mantovani R, Bailoni L, Contiero B \& Bittante G (1996). Change in body condition score of Holstein cows as affected by parity and mature equivalent milk yield. Journal of Dairy Science 79(6): 1009-1015

Gallo L, Carnier P, Cassandro M, Dal Zotto R \& Bittante $\mathrm{G}$ (2001). Test-day genetic analysis of condition score and heart girth in Holstein Friesian cows. Journal of Dairy Science 84(10): 2321-2326

Grosshans T, Xu Z Z, Burton L J, Johnson D L \& Macmillan K L (1997). Performance and genetic parameters for fertility of seasonal dairy cows in New Zealand. Livestock Production Science 51(1): 41-51

ICAR (2004). International Agreement of Recording Practices, ICAR Recording Guidelines, pp. 391

Kadarmideen H N \& Wegmann S (2003). Genetic parameters for body condition score and its relationship with type and production traits in Swiss Holsteins. Journal of Dairy Science 86(11): 36853693

Kadarmideen H N (2004). Genetic correlations among body condition score, somatic cell score, milk production, fertility and conformation traits in dairy cows. Animal Science 79(2): 191-201
Karslığlu Kara N (2015). Siyah Alaca 1rkı ineklerde vücut kondisyon skorunun döl verim parametrelerine etkisi. Doktora tezi, Uludağ Üniversitesi Fen Bilimleri Enstitüsü (Basılmamış), Bursa

Kellogg W (2016). Body Condition Scoring with Dairy Cattle.http://www.uaex.edu/publications/pdf/FSA4008.pdf (Accessed date: 29.03.2016)

Koenen E P C, Veerkamp R F, Dobbelaar P \& De Jong G (2001). Genetic analysis of body condition score of lactating Dutch Holstein and Red-and-White heifers. Journal of Dairy Science 84(5): 1265-1270

Loker S, Bastin C, Miglior F, Sewalem A, Schaeffer L R, Jamrozik J, Ali A \& Osbornell V (2012). Genetic and environmental relationships between body condition score and milk production traits in Canadian Holsteins. Journal of Dairy Science 95(1): 410-419

Mrode R A (1996). Linear Models for the Prediction of Animal Breeding Values. Cab International, Wallingford

NFACC (2016). Body Condition Scoring Chart. http:// www.nfacc.ca/body-condition-scoring-dairy-cow (Accessed date: 18.02.2016)

Pryce J E, Coffey M P \& Brotherstone S (2000). The genetic relationship between calving interval, body condition score and linear type and management traits in registered Holsteins. Journal of Dairy Science 83(11): 2664-2671

Robinson J J (1986). Changes in body composition during pregnancy and lactation. Proceedings of the Nutrition Society 45(1): 71-80

Royal M D, Flint A P F \& Woolliams J A (2002a). Genetic and phenotypic relationships among endocrine and traditional fertility traits and production traits in Holstein-Friesian dairy cows. Journal Dairy Science 85(4): 958-967

Royal M D, Pryce J E, Woolliams J A \& Flint A P (2002b). The genetic relationship between commencement of luteal activity and calving interval, body condition score, production, and linear type traits in HolsteinFriesian dairy cattle. Journal of Dairy Science 85(11): 3071-3080

Ruegg P L \& Milton R L (1995). Body condition scores of Holstein cows on Prince Edward Island, Canada: Relationships with yield, reproductive performance, and disease. Journal of Dairy Science 78(3): 552-564

Staples C R, Thatcher W W, Garcia-Bojalil C M \& Lucy M C (1992). Nutritional influences on reproductive function. In: H H Van Horn (Ed), Large Dairy Herd 
Management, American Dairy Science Association, Champaign, IL, pp. 382-392

Şahin O (2011). Süt Sığırlarında Tip Sinıflandırması ve Vücut Kondisyonu Değerlendirme. Cattle Breeders' Association of Turkey, Ankara

Vallimont J E, Dechow C D, Daubert J M, Dekleva M W, Blum J W, Barlieb C M, Liu W, Varga G A, Heinrichs A J \& Baumrucker C R (2010). Genetic parameters of feed intake, production, body weight, body condition score, and selected type traits of Holstein cows in commercial tie-stall barns. Journal of Dairy Science 93(10): 4892-4901

Veerkamp R F \& Emmans G C (1995). Sources of genetic variation in energetic efficiency of dairy cows. Livestock Production Science 44(2): 87-97

Veerkamp R F \& Brotherstone S (1997). Genetic correlations between linear type traits, food intake, live weight and condition score in Holstein Friesian dairy cattle. Animal Science 64(3): 385-392

Veerkamp R F, Koenen E P C \& De Jong G (2001). Genetic correlations among body condition score, yield, and fertility in first-parity cows estimated by random regression models. Journal of Dairy Science 84(10): 2327-2335

Waltner S S, McNamara J P, Hillers J K \& Brown D L (1994). Validation of indirect measures of body fat in lactating cows. Journal of Dairy Science 77(7): 25702579

Wildmann E E, Jones G M, Wagener P E, Boman R L, Troutt Jr H F \& Lesch T N (1982). A dairy cow body condition scoring system and its relationship to selected production characteristics. Journal of Dairy Science 65(3): 495-501 